\title{
CORRELATIVE STUDY BETWEEN SERUM MATRIX METALLOPROTEINASE 9 VALUES AND NEUROLOGIC DEFICIT IN ACUTE, PRIMARY, SUPRATENTORIAL, INTRACEREBRAL HAEMORRHAGE
}

\author{
Dragana Petrovska-Cvetkovska, Natalija Dolnenec-Baneva, Dijana Nikodijevik, \\ Tatjana Chepreganova-Changovska
}

University Clinic of Neurology, Faculty of Medicine, Ss. Cyril and Methodius University, Skopje, R Macedonia

Corresponding Author: Dragana Petrovska Cvetkovska, University Clinic of Neurology, Faculty of Medicine,

Ss Cyril and Methodius University, Skopje, R Macedonia, Lerinska 57b, Skopje; Tel: +389 (0)2 784515 50;

E-mail: drdragana76@gmail.com; drdraganaa@yahoo.com

\begin{abstract}
One of the essential characteristics of intracerebral haemorrhages (ICH) is the occurrence of brain oedema (BE). Matrix metalloproteinase-9 (MMP-9) belongs to the family of proteolytic enzymes connected with zinc, which in brain bleeding or a stroke can induce matrix proteolyse into the neurovascular unit, and increase the BE. The aim of the study was to determine the MMP-9 values in serum, and to assess the degree of correlation with neurological deficit in patients with acute, primary and supratentorial ICH.

Materials: The study was prospective and included 62 patients with ICH. The neurological deficit of the patients was evaluated by the National Institute Health Stroke Scale (NIHSS). Serum MMP-9 level was determined by enzyme-linked immune sorbent assay (ELISA). Patients were evaluated in three phases: $1^{\text {st }}, 3^{\text {rd }}$ and $7^{\text {th }}$ day following the ICH.

Results: The mean age of the patients was $64.5 \pm 9.4$. Within the follow-up period, there was a significant rise of the NIHSS score in the first three days: $11.48 \pm 3.7 ; 13.21 \pm 3.78$, and a significant rise of serum MMP-9, with greatest values in the third day: $134.7 \pm 26.1 \mathrm{ng} / \mathrm{ml}(\mathrm{p}=0.000)$. There was a positive, significant correlation $(\mathrm{r}=0.886, \mathrm{p}=0.000)$ between the serum MMP-9 concentration and the NIHSS score.

Conclusion: Our study showed that in the first three days of ICH, serum MMP-9 values were rising as well as the neurological deficit and the BE. Determination and evaluation of the MMP-9 in serum is an easy, non-invasive, routine laboratory procedure for the detection and follow-up of BE, and also determines further therapeutic strategy as well as prognosis in these patients.
\end{abstract}

Key words: intracerebral haemorrhage, brain oedema, matrix metalloproteinase-9.

\section{Introduction}

Intracerebral haemorrhage $(\mathrm{ICH})$ is an acute cerebrovascular disease which occurs by brain artery rupture and extravasation of blood in the surrounding brain parenchyma. It is present in $10-15 \%$ of all types of stroke [1].

Primary ICHs are divided into two types: the hypertensive type (present in 60\%) are due to a rupture of the lipohyaline changed blood vessel, in a condition of the existence of arterial hypertension (HTA), and the non-hypertensive type (present in 20\%) due to the existence of amyloid angiopathy, with no presence of HTA. According to the localization, ICH is divided into supratentorial and infratentorial. Supratentorial $\mathrm{ICH}$ is represented in the highest percentage of all $\mathrm{ICH}$, with $85 \%$. These, again, are divided into lobar and deep brain bleedings [2].

In $\mathrm{ICH}$, the blood extravasates through a small rupture, most frequently from a small 
intraparenchymal (mostly penetrating) artery, and penetrates the brain parenchyma. Extravasated blood causes dislocation, compression and destruction of the surrounding tissue (primary damage) but also secondary damage, with the occurrence of surrounding ischaemia and perifocal brain oedema (BE) [3].

An essential ICH characteristic is the development of surrounding BE, because it increases the parenchymatous vascular lesion produced by the action of extravasated blood. BE has occured even in the first hour of bleeding, reaching maximal magnitude in the 3-5 day following the occurrence of bleeding. Within the process of regression of the intracerebral haematoma the BE also starts decreasing [4].

Matrix metalloproteinases (MMP) are gelatinases and belong to the family of proteolytic enzymes connected with zinc, which in normal conditions re-model the extracellular matrix. In non-adequate activation, they can induce matrix proteolyse in the neurovascular unit (including endothelium, astrocytes and neurons).

The balance between the proteases and their inhibitors decides if there will be a proteolysis of the extracellular matrix, or if the matrix will stay intact. Gelatinase-A normally exists in brain tissue in latent form and is activated by membrane-boundary proteases or the membrane-type metalloproteinases. Gelatinase-B is produced in brain tissue in a state of rest or stimulation. Astrocytes in normal, physiological conditions produce gelatinase- $\mathrm{B}$ in a latent form, and microglia cells after the stimulation of the pro-inflammatory cells: cytokines and tumour necrotizing factor. Cerebral capillaries produce gelatinase, while the neutrophils produce gelatinase, elastase and cathepsin when the blood vessel wall disrupts and there is a consequently secondary inflammatory response. This occurs even within the first 24 hours following the damage to the blood-brain barrier (BBB); when it is maximally open and vulnerable, the proteases, including gelatinase, attack the basal lamina, which in its constitution contains collagen type IV, laminin and fibronectin. Then the fall of the inhibitors follows, which interferes with the damage to the BBB and the BE [5].

Rosenberg and Navratil (1997), Lapchak et al. (2000) and Pfefferkorn et al (2003) showed a rise of MMP-9 in patients with haemorrhagic complication of an ischaemic stroke with tissue plasminogen activator, while administration of synthesized inhibitors MMP (BB101 or BB-94) decrease the ME and mortality rate in these patients [6-8].

Jose-Avarez-Sabit et al. (2004) investigated the MMP-2, MMP-3 and MMP-9 as well as their inhibitors (TIMP 1 and TIMP2) in patients with ICH. The results of the study showed the highest value of MMP2 and TIMP 2 within the first hours of ICH ( $<12$ hours), MMP 9 and TIMP 1 had the highest values in the first 24 hours, while MMP 3 had the highest value in plasma from 24-48 hours [9].

The aim of the study was to determine the MMP-9 values in serum, and to assess the degree of correlation with neurological deficit in patients with acute, primary and supratentorial $\mathrm{ICH}$.

\section{Material and methods}

The investigation represented a longitudinal and randomized, open-labelled study of clinical evaluation of the neurological deficit in acute, primary and supratentorial ICH depending on the serum MMP-9 values. A total of 62 selected patients with acute, primary and supratentorial ICH were admitted and followed-up at University Clinic of Neurology, Skopje. A control group of 62 (conditionally) healthy examinees were included, due to the analysis and quantification of the plasma MMP-9.

When entering the study each of the examinees underwent detection of haematoma and perifocal oedema, performed on the computerized tomography for the brain, using Somatom apparatus "Balance" SIEMENS.

Vein blood specimens were taken in citrate and EDTA tubes from each patient. Vein blood was immediately centrifuged on 3000 turnings (rpm) for 15 minutes and then serums were separated and frozen at $-80^{\circ} \mathrm{C}$. Centrifuging, freezing and keeping of specimens was done at the Biochemical Laboratory of the Clinic of Neurology, Skopje.

Serum MMP-9 level was determined by enzyme-immune-analysis with the ELISA technique (enzyme-linked immune sorbent assay) by standardized methods and reagents, according to the assigned protocol by the manufacturer - Biotrack; Amersham Pharmacia (UK). 
ELISA analyses in serum samples were made on the spectrophotometer UV-Vis Cary 50 (manufactured by Varian), in the Institute for Chemistry at the Faculty of Sciences. The obtained data were expressed in $\mathrm{ng} / \mathrm{ml}$. According to recently published studies from other laboratories, the MMP 9 serum reference values (in healthy individuals), range in values $<72$ $\mathrm{ng} / \mathrm{ml}[10]$.

The National Institute Health Stroke Scale (NIHSS) was used for evaluation of the neurological condition in stroke for assessment of the examinees' neurological state, the NIHSS scale analyses of 15 items (fields) of the neurological status and every item contains a corresponding total score, which unites the scores from the ranks of different capturing. Ranking of the total score ranged from 0 without a deficit to a maximum - 36 , the most difficult neurologic deficit [11].

Concerning the values of the NIHSS scores for the neurological deficit, this is categorized in four groups: minor neurological deficit with a score from 1 to 4 ; moderate with a score from 5 to 15 , averagely severe with a score from 16 to 20; and severe neurological deficit with a score of 21 .

Evaluation of the patients by serum MMP-9 values and neurological deterioration (using NIHSS score), was realized in three phases: $1^{\text {st }}, 3^{\text {rd }}$ and $7^{\text {th }}$ day following the $\mathrm{ICH}$.

\section{Results}

The gender structure of the examinees was 28 (45.2) male examinees and 34 (54.8\%) females. The mean age of the investigated individuals was $64 \pm 9.4$ years, in range 44-89 years. Eighty-six percent of the patients had a history of chronic hypertension.
Analysis and quantification of serum matrix metalloproteinase's (MMP-9) was made in this investigation of 62 conditionally healthy examinees, representing the control group.

The mean value of thee proteolytic enzymes in the group of healthy examinees are shown in Figure 1.

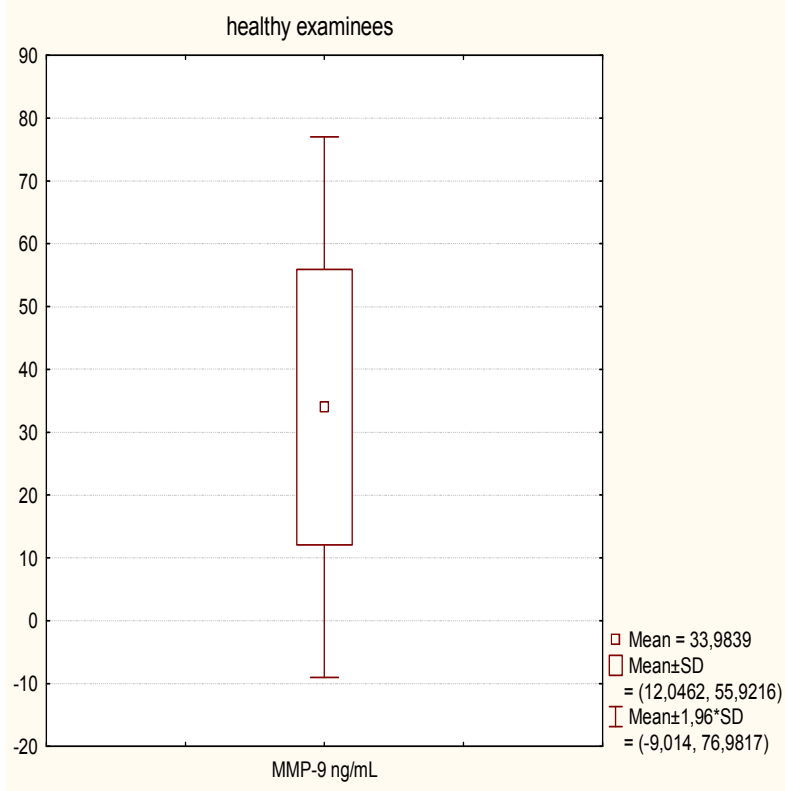

Figure 1 - The value of MMP-9 in serum, in conditionally healthy examinees

Table 1 shows the values of the serum MMP 9, and the differences between the three phases of evaluation, in patients with $\mathrm{ICH}$.

The mean score on the NIHSS scale and the differences between the first days following the ICH occurrence, are shown in Table 2.

The classification of the patients with ICH in groups by neurological deficit, evaluated using the NINSS, is shown in Table 3.

Table 1

Values and difference between serum MMP-9 values in the three phases of evaluation

\begin{tabular}{|l|c|c|c|c|c|}
\hline MMP-9 & $\mathbf{n}$ & mean \pm SD & min-max & median & $\mathbf{2 5}-\mathbf{7 5}$ percentiles \\
\hline I day & 62 & $127.86 \pm 25.4$ & $86-181,5$ & 124.9 & $110.4-147.5$ \\
\hline III day & 62 & $134.7 \pm 26.1$ & $90.4-191$ & 132.85 & $114.7-155.5$ \\
\hline VII day & 62 & $117.0 \pm 25.2$ & $69.3-175.8$ & 110.65 & $100.4-137.4$ \\
\hline
\end{tabular}

day I/III/VII Friedman ANOVA Chi Sqr. $(\mathrm{N}=62, \mathrm{df}=2)=124.0000 \mathrm{p}=0.000 * *$

day $\quad$ I/III Wilcoxon Matched Pairs Test $Z=6.85 \mathrm{p}=0.000^{* *}$

day I/VII Wilcoxon Matched Pairs Test $Z=6.85 \mathrm{p}=0.000^{* *}$

day III/VII Wilcoxon Matched Pairs Test $Z=6.85 \mathrm{p}=0.000^{* *}$ 
Table 2

Mean scores and differences between NIHSS scale in the three phases of evaluation

\begin{tabular}{|c|c|c|c|c|c|}
\hline NIHSS score & $\mathbf{n}$ & mean \pm SD & min-max & median & 25-75 percentiles \\
\hline I day & 62 & $11.48 \pm 3.7$ & $6-20$ & 12 & $8-14$ \\
\hline III day & 62 & $13.21 \pm 3.78$ & $6-22$ & 13 & $10-16$ \\
\hline VII day & 62 & $11.26 \pm 3.86$ & $4-22$ & 11 & $8-14$ \\
\hline
\end{tabular}

Friedman ANOVA Chi Sqr. $(\mathrm{N}=62, \mathrm{df}=2)=93,80734 \mathrm{p}=0,000^{* *}$

day I I III Wilcoxon Matched Pairs Test $Z=6,45 \mathrm{p}=0,000^{* *}$

day I / VII Wilcoxon Matched Pairs Test $Z=1,09 \mathrm{p}=0,28$

day III / VII Wilcoxon Matched Pairs Test $Z=6,74 p=0,000^{* *}$

Table 3

Classification of patients with ICH in groups by neurological deficits (n.d)

\begin{tabular}{|l|c|c|c|}
\hline NIHSS score & I day & III day & VII day \\
\hline $1-4$ minor .d & $/$ & $/$ & $1(1.61 \%)$ \\
\hline $5-15$ moderate .d & $52(83.87 \%)$ & $45(72.58 \%)$ & $51(82.26 \%)$ \\
\hline $16-20$ moderate to severe n.d & $10(16.13 \%)$ & $17(27.42 \%)$ & $9(14.52 \%)$ \\
\hline$>21$ severe n.d & $/$ & $/$ & $1(1.61 \%)$ \\
\hline Total & 62 & 62 & 62 \\
\hline
\end{tabular}

Figure 2 shows the correlation between the serum MMP-9 concentration of the examinees with intracerebral haemorrhage and the NIHSS scores

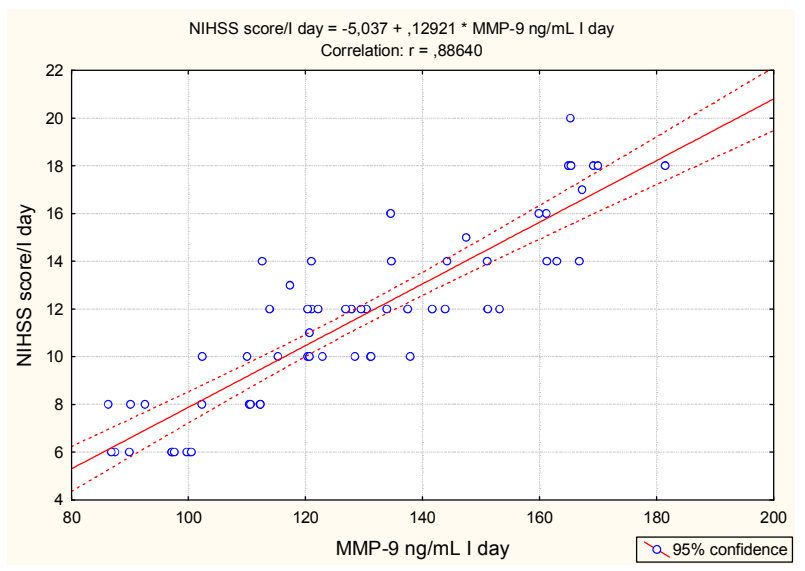

Figure 2 - Correlation between serum MMP-9 values $\mathrm{r}=0,886 \mathrm{p}=0,000^{* *}$ and NIHSS scores

\section{Discussion}

A total of 62 selected patients with acute, primary, supratentorial intracerebral haemorrhage were included in this study. Intracerebral haemorrhage is a cerebrovascular disease which is more frequently represented at an age above 50 years [13]. In our study, the mean age of the included patients was $64.5 \pm 9.4$ years, which corresponds with the statistical multi-centric world studies. The gender distribution was shown to be in favour of the females, while the world statistics show that it is more frequently represented in men than in women [14].

The leading risk factor for ICH occurrence is chronic HTA, being represented in 72$81 \%$ of the patients. Chronic HTA increases the risk of bleeding by $4-5$ times. In the study of 62 patients, a positive anamnesis or previously diagnosed and treated HTA was found in $86 \%$ of the patients from inspection of their medical records.

The mean value of these proteolytic enzymes was $33.98 \pm 21.9 \mathrm{ng} / \mathrm{ml}$ in our study of healthy individuals which correlated with the reference plasma MMP-9 values in previously made studies.

The results of the serum MMP-9 values showed high values even within the first 24 hours, reaching its peak in the third day, and a fall of the values in the seventh day following the ICH occurrence. Statistical analysis proved the differences of serum MMP-9 values in the analyzed period, days I/III/VII, as highly significant $(\mathrm{p}=0.000)$. A previously conducted 
study showed the highest MMP-9 values within the first 48 hours from the blood vessel rupture, which was similar to our results [15].

The estimation of the neurologic deficit (with NIHSS score) showed a statistically significant rise in the score, i.e. a more severe neurologic deficit was followed on the third day, when also some of the patients with a moderate neurologic deficit passed into the group with an averagely severe neurologic deficit, in the period when the serum MMP-9 values were the highest, respectively.

Correlation between the serum MMP-9 concentration and the NIHSS scores of the examinees with acute, primary, supratentorial ICH showed a positive and very strong, and highly significant $r=0.886$ and $p=0.000$. This indicated that elevation of the serum MMP-9 concentration raised the NIHSS scores, and also raised the neurological deficit progressed in these patients, respectively.

The rise of serum MMP-9 in the first 3-5 days following the occurrence of the acute, primary, supratentorial intracerebral haemorrhage suggests a destruction of the extracellular matrix even in the first hours of haematoma development. Destruction and proteolysis of the extracellular matrix has been due, most probably, to a rise of periphocal BE, in which cascades of proteolytic and necrotizing factors participate, which consequently also activate the complement [16].

Recent studies investigate the therapeutic effects of inhibitors of MMP-9 as possible new therapeutic agents for treatment of BE $[17,18]$

\section{Conclusion}

The results of our study showed that the level of the serum MMP-9 rise and the neurologic deficit progresses in the first three days following the occurrence of the acute, primary, supratentorial ICH. The values of serum MMP9 rise in the first days of brain bleeding, and this is a period when BE is developing. Determination and follow-up of the serum MMP-9 is an easy routine laboratory procedure and a parameter for the quick determination and followup of the BE, as well as prognostic one in the case of ICH patients. This is of great therapeutic importance in the management of patients with brain bleeding.

\section{REFERENCES}

1. Adams DR, Victor M. Principles of Neurology. New York, Mc Graw-Hill Inc, 1993.

2. Skidmore CT, Andrefsky J. Spontaneous intracerebral hemorrhage: epidemiology, patophysiology, and medical menagement. Neurosurg Clin N Am. 2002; 13: 281-288.

3. Bahemuka M, Primary intracerebral hemorrhagy and heart weight: a clinicopathological case control review of 218 patients. Stroke. 1987; 18: 531-536.

4. Huang FP, Xi G, Keep RF, et al. Brain edema after experimental intracerebral hemorrage; Role of hemglobin degradation products. J Neurosurg. 2002; 96: 287-293.

5. Nagase H. Activation mechanisms of matrix metaloproteinases. Biol Chem. 1997; 378: 151-160.

6. Rosenberg G, Navratil M. Metalloproteinase inhbition blocks edema in intracerebral hemorrhage in the rat. Neurology. 1997; 48: 921-926.

7. Lapchak P, Chapman D, Zivin J. Metalloproteinase inhibition reduces thrombolytic (tissue plasminogen activator)-induced hemorrhage after thromboembolic stroke. Stroke. 2000; 31: 3034-40.

8. Pfefferkorn T, Rosenberg G. Closure of the bloodbrain barrier by matrix metalloproteinase inhibition reduces rtPA-mediated mortality in cerebral ischemia with delayed reperfusion. Stroke. 2003; 34: 2025-30.

9. Alvarez-Sabin J, Delgado P, Abilleira S, Molina C, Arenillas J, Ribo M, et al. Temporal profile of matrix metalloproteinases and their inhibitors after spontneous intracerebral hemorrhage: relationship to clincal and radiological outcome. Stroke. 2004; 35: 1316-22.

10. Abilleira S, Montaner J, Molin C, et al. Matrix metaloproteinase-9 contretation after spontaneous intracrebral hemorrhage. J Neurosurg. 2003; 99: 65-70.

11. De Graba JT, Hallenbeck MJ, Pettigrew DK, et al. Progresion in acute stroke: Value of the initial NIH stroke scale score on patients stratification in future trials. Stroke. 1999; 30: 1208-1212.

12. Baird AE, Dasche J, Connor A, et al. Comparision of retrospective and prospecive measurements of the national institutes of health stroke scale. Cerebrovasc Dis. 2000; 10: 80-81.

13. Пемов П. Цереброваскуларни болести Скопје: Култура. 2004.

14. Adams H. Handbook of cerebrovascular disease. New York: Dekker; 1996

15. Abilleira S, Montaner J, Molin C, et al. Matrix metalloproteinase- 9 contretation after spontaneous intracerebral hemorrhage. J Neurosurg 2003; 99: 65-70.

16. Leira R, Davalos A, Silva Y, et al. Stroke Project, Cerebrovascularis Diseases Group of Spanish Neurological Society. Early neurological deterioration in intracerebral hemorrage: predictors and associated factors. Neurology. 2004; 63: 461-467.

17. Tejima E, Guo S, Murata Y, et al. Neuroprotective effects of overexpressing tissue inhibitor of metalloproteinase TIMP-1. J Neurotrauma. 2009; 26(11): 1935-1941. 
18. Mahajan SD, Aalinkeel R, Reynolds JL, et al. Suppression of MMP-9 expression in brain microvascular endothelial cells (BMVEC) using a gold nanorod (GNR)-siRNA nanoplex. Immunol Invest. 2012; 41(4): 337-355.

Резиме

\section{КОРЕЛАТИВНА СТУДИЈА \\ НА ВРЕДНОСТИТЕ НА МАТРИКС \\ МЕТАЛОПРОТЕИНАЗА 9 ВО СЕРУМ \\ И НЕВРОЛОШКИОТ ДЕФИЦИТ \\ КАЈ АКУТНА, ПРИМАРНА, СУПРАТЕНТОРИЈАЛНА, ИНТРАЦЕРЕБРАЛНА ХЕМОРАГИЈА}

\section{Драгана Петровска-Цветковска, Наталија Долненец-Банева, Дијана Никодиевиќ, \\ Татјана Чепреганова-Чанговска}

Универзитетска клиника за неврологија, Скопје, Медицински факултет, Универзитет „Св. Кирил и Методиј“, Скопје, Р. Македонија

Една од битните карактеристики на интрацеребралната хеморагија (ИЦХ) е настанувањето на околниот мозочен едем (ME). Матрикс металопротеиназа-9 (ММП-9) припаѓа на голема фамилија протеолитични ензими поврзани со цинк, кои кај мозочно крвавење и мозочен удар индуцираат протеолиза на матриксот, во склоп на невроваскуларната единица, и доведуваат до пораст на МЕ.

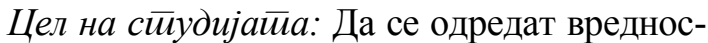
тите на ММП-9 во серум кај акутна примарна, супратенторијална ИЦХ и да се процени степенот на корелација со невролошкиот дефицит кај пациенти со акутна, примарна, супратенторијална ИЦХ.

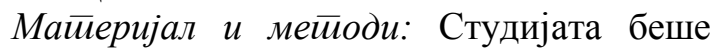
проспективна, и во неа беа вклучени 62 пациенти со ИЦХ. Невролошкиот дефицит на пациентите беше евалуиран со скалата за удари од Националниот институт за здравје (NIHSS). Нивото на ММП-9 во серум се одреди со ензимоимуноанализа со ЕЛИСА-техника (enzyme-linked immune sorbent assay). Евалуацијата на пациентите беше реализирана во три фази: прв, трет и седми ден од ИЦХ.

Резулйайи: Просечната старост кај пациентите изнесуваше $64,5 \pm 9,4$. Во периодот на испитувањето се следеше сигнификантен пораст на NIHSS скорот првите три дена: $11,48 \pm 3,7$; $13,21 \pm 3,78$, и значаен пораст на ММР-9 во серум, со најголеми вредности третиот ден од следење: $134,7 \pm 26,1 \mathrm{ng} / \mathrm{ml}(\mathrm{p}=0,000)$. Помеѓу концентрацијата на МMP-9 во серумот на испитаниците со интрацеребрална хеморагија и скоровите од NIHSS скалата, постои позитивна, сигнификантна корелација $(\mathrm{r}=0,886 \mathrm{p}=0,000)$.

Заклучок: Студијата покажа дека првите денови од ИЦХ, вредностите на серумските ММП-9 растат исто како и невролошкиот дефицит и МЕ. Одредувањето и евалуацијата на ММП-9 во серум се едноставна, неинвазивна, рутинска лабораториска процедура за одредување и следење на ME, како и прогноза на пациентите со ИЦХ. Ова е од огромно значење за одредување на понатамошната тераписка стратегија, како и прогноза на овие пациенти.

Клучни зборови: интрацеребрална хеморагија, мозочен едем, матрикс металопротеиназа-9. 